\title{
Biogeochemical cycling at the aquatic-terrestrial interface is linked to parafluvial hyporheic zone inundation history
}

\author{
Amy E. Goldman, Emily B. Graham, Alex R. Crump, David W. Kennedy, Elvira B. Romero, Carolyn G. Anderson, \\ Karl L. Dana, Charles T. Resch, Jim K. Fredrickson, and James C. Stegen \\ Pacific Northwest National Laboratory, Richland, WA 99352, USA \\ Correspondence to: Amy E. Goldman (amy.goldman@pnnl.gov)
}

Received: 1 February 2017 - Discussion started: 20 February 2017

Revised: 15 August 2017 - Accepted: 23 August 2017 - Published: 21 September 2017

\begin{abstract}
The parafluvial hyporheic zone combines the heightened biogeochemical and microbial interactions indicative of a hyporheic region with direct atmospheric/terrestrial inputs and the effects of wet-dry cycles. Therefore, understanding biogeochemical cycling and microbial interactions in this ecotone is fundamental to understanding biogeochemical cycling at the aquatic-terrestrial interface and to creating robust hydrobiogeochemical models of dynamic river corridors. We aimed to (i) characterize biogeochemical and microbial differences in the parafluvial hyporheic zone across a small spatial domain (6 lateral meters) that spans a breadth of inundation histories and (ii) examine how parafluvial hyporheic sediments respond to laboratory-simulated re-inundation. Surface sediment was collected at four elevations along transects perpendicular to flow of the Columbia River, eastern WA, USA. The sediments were inundated by the river $0,13,127$, and 398 days prior to sampling. Spatial variation in environmental variables (organic matter, moisture, nitrate, glucose, $\% \mathrm{C}, \% \mathrm{~N}$ ) and microbial communities (16S and internal transcribed spacer (ITS) rRNA gene sequencing, qPCR) were driven by differences in inundation history. Microbial respiration did not differ significantly across inundation histories prior to forced inundation in laboratory incubations. Forced inundation suppressed microbial respiration across all histories, but the degree of suppression was dramatically different between the sediments saturated and unsaturated at the time of sample collection, indicating a binary threshold response to re-inundation. We present a conceptual model in which irregular hydrologic fluctuations facilitate microbial communities adapted to local conditions and a relatively high flux of $\mathrm{CO}_{2}$. Upon rewetting, microbial communities are ini-
\end{abstract}

tially suppressed metabolically, which results in lower $\mathrm{CO}_{2}$ flux rates primarily due to suppression of fungal respiration. Following prolonged inundation, the microbial community adapts to saturation by shifting composition, and the $\mathrm{CO}_{2}$ flux rebounds to prior levels due to the subsequent change in respiration. Our results indicate that the time between inundation events can push the system into alternate states: we suggest (i) that, above some threshold of inundation interval, re-inundation suppresses respiration to a consistent, low rate and (ii) that, below some inundation interval, re-inundation has a minor effect on respiration. Extending reactive transport models to capture processes that govern such dynamics will provide more robust predictions of river corridor biogeochemical function under altered surface water flow regimes in both managed and natural watersheds.

\section{Introduction}

The hyporheic zone, the subsurface region where river water and groundwater $(\mathrm{GW}) \mathrm{mix}$, is characterized by heightened biogeochemical cycling and microbial interactions (McClain et al., 2003; Boulton et al., 2010; Mulholland and Webster, 2010; Stegen et al., 2016). Hyporheic sediment is exposed to different aquatic chemistries due to variation in hydraulic head that drives flow into and out of the hyporheic zone (Arntzen et al., 2006; Hucks Sawyer et al., 2009). When river elevation rises, river water infiltrates hyporheic sediment. When river elevation falls, outflow from the hyporheic zone consists of both bank storage, which contains river water altered by hyporheic biogeochemical transformation (Wörman et al., 2002), and groundwater flowing out to the river through 
the hyporheic zone (Boano et al., 2008). Many prior studies have focused on the main channel hyporheic zone that is continuously overlain by a column of water (e.g., Boulton et al., 1998, 2010; Tonina and Buffington, 2009; Mulholland and Webster, 2010; Trimmer et al., 2012). However, the parafluvial hyporheic zone (Fig. 1), located in the region of the river channel that is dry during low flows, presents an important location to investigate biogeochemical cycling at the aquatic-terrestrial interface because it combines the prominent interactions of a hyporheic region with the addition of direct atmospheric/terrestrial inputs and the effects of wet-dry cycles. Given that the parafluvial zone is present in all river systems, understanding biogeochemical cycling and microbial interactions in this ecotone is fundamental to understanding the coupling between aquatic and terrestrial biogeochemical cycles.

In the United States, 2653 dams generate hydropower (USACE, 2016), and $90 \%$ of water discharge is hydrologically altered (Jackson et al., 2001). Hydropower currently accounts for $80 \%$ of renewable energy globally (Zarfl et al., 2015; Hermoso, 2017) and is projected to increase as countries begin managing their energy production within the Paris Agreement and other climate accords (Hermoso, 2017; Latrubesse et al., 2017). In dam-controlled watersheds, the parafluvial hyporheic zone undergoes rapid cycles of wetting and drying caused by hydropeaking regimes in which flow is intentionally maximized during times of high energy demand and/or fish migration. In the Hanford Reach of the Columbia River, for example, hydropower dam operations cause river water elevation to fluctuate up to $2 \mathrm{~m}$ in a single day (Arntzen et al., 2006). Over time, cycles of wetting and drying impact different elevations of the parafluvial zone at different frequencies, which not only naturally results in a gradient of sediment moisture content but also has the potential to create biogeochemical and microbial interactions specifically dependent on preceding environmental conditions (Hupp and Osterkamp, 1996; Larned et al., 2010; Tockner et al., 2000; Hawkes et al., 2017). Given that dam-impacted parafluvial zones are globally ubiquitous and likely to expand with ongoing dam construction efforts, there is a need to identify the processes impacted by the history of variable inundation. Doing so will unlock new possibilities to understand linkages among hydrology, biogeochemistry, and microbial ecology on a systems level and ultimately use that knowledge to develop robust hydrobiogeochemical models for application in dam-impacted systems.

Previous studies of biogeochemical cycling in the parafluvial zone have sampled gravel bars to investigate hydrologic flow paths (Claret and Boulton, 2008; Deforet et al., 2009; Zarnetske et al., 2011) and have sampled during saturated conditions utilizing well/piezometer transects (Baker et al., 1999; Deforet et al., 2009; Briody et al., 2016; Graham et al., 2016; Stegen et al., 2016). Such studies have indicated that the parafluvial hyporheic zone is an active region of diverse biogeochemical transformations (Zarnetske et al.,
2011; Briody et al., 2016) and microbial community dynamics (Baker et al., 1999; Graham et al., 2016, 2017; Stegen et al., 2016), often influenced by residence times (Claret and Boulton, 2008; Deforet et al., 2009; Zarnetske et al., 2011). However, studies that have compared biogeochemical cycling in the parafluvial zone to other floodplain environments (e.g., forest, ponds, islands, wetlands) have found that stream and nearby gravel habitats have had lower respiration, bacterial abundance, enzyme activities, and sediment nitrogen nutrient leaching than adjacent pasture/grassland, vegetated islands, and/or mature forest habitats, but short flood pulses ( $24 \mathrm{~h})$ have increased bacterial extracellular enzymes in sediment from both flooded riverbanks and wetlands (Burns and Ryder, 2001; Doering et al., 2011; Ostojić et al., 2013; Bodmer et al., 2016). With regard to wet-dry cycles, many studies have examined their biogeochemical and microbial effects in terrestrial soils (Jarvis et al., 2007, and references therein; Kim et al., 2012, and references therein). Fewer have investigated them in intermittent stream sediments, wherein the entire stream dries for stretches of time (Leigh et al., 2016, and references therein). Zeglin et al. (2011) investigated parafluvial transects of two intermittent streams located in cold (Antarctic) and hot (New Mexico, US) deserts and identified binary microbial community (16S rRNA gene sequencing) differences based on wet vs. dry sediments in both environments.

Prior work has not examined how inundation history and wet-dry cycles influence biogeochemical cycling and microbial communities within a hydropower-influenced transect of the parafluvial hyporheic zone and has not investigated the degree to which response to rewetting is due to inundationhistory-driven microbial community composition or aqueous chemistry. Determining drivers of biogeochemical-microbial interactions in the parafluvial zone will elucidate the implications of climate-watershed interactions on biogeochemical cycling, which will aid understanding of both managed river systems and related ecosystems (e.g., intermittent streams, tidally influenced littoral zones of the Great Lakes).

To fill knowledge gaps in parafluvial biogeochemical cycling dynamics, we aimed to (i) characterize differences in sediment biogeochemistry and microbial communities (bacteria, archaea, and fungi) in the parafluvial hyporheic zone across a spatial domain of 6 lateral meters that integrates a breadth of inundation histories and (ii) examine how the sediments respond to laboratory-simulated re-inundation. In order to determine the re-inundation response under different GW-river water mixing scenarios, we used three different re-inundation waters to capture the influence of cation content (typically higher in $\mathrm{GW}$ ), $\mathrm{NO}_{3}^{-}$concentration (typically higher in GW), and availability of dissolved organic carbon (typically higher in river water). We expected to observe higher amounts of carbon (e.g., organic matter, glucose) at the upper elevations where it could accumulate away from the physical mixing and dilution of inundation and subsequently greatest respiration at the drier upper elevations 

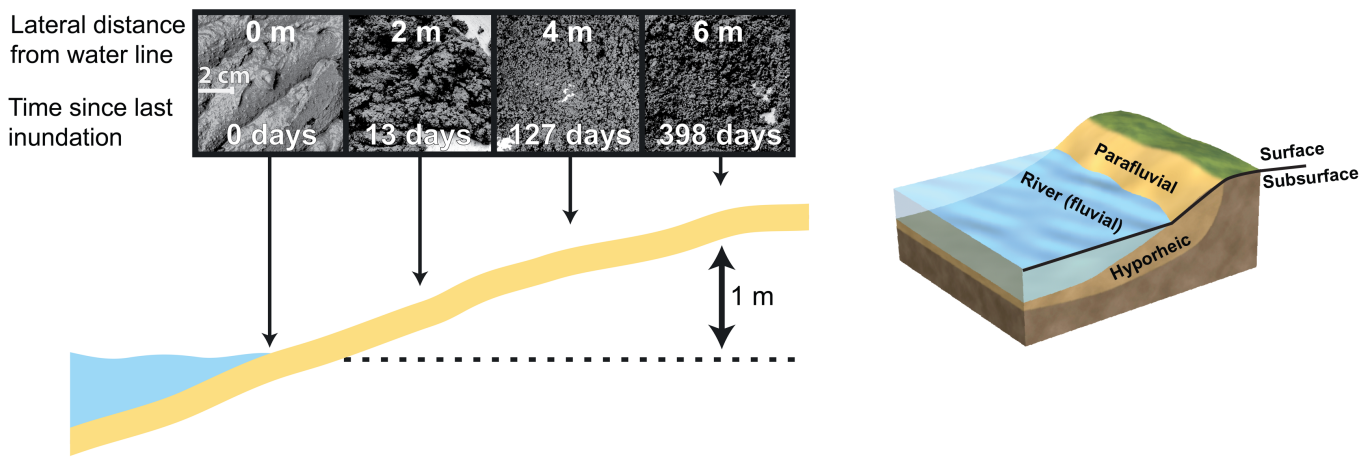

Figure 1. Diagram of parafluvial hyporheic zone and of sampling design with photographs of sieved sediment sampled. The four locations were spaced laterally at $2 \mathrm{~m}$ intervals beginning at the water line and encompassed $1 \mathrm{~m}$ of elevation change. Note changes in sediment moisture and texture with changes in inundation history.

following rewetting (e.g., the "Birch effect"; Birch, 1958). We identified two opposing hypotheses to determine additional drivers of microbial respiration across an elevational transect of the parafluvial hyporheic zone. First, we hypothesized that recreating the GW-river water mixing that occurs in the hyporheic zone would stimulate respiration regardless of inundation history, because GW-surface water mixing brings complementary electron donors and acceptors together (McClain et al., 2003). Alternately, we hypothesized that inundation history is a more important driver of respiration response, such that local adaptation of the microbial community due to inundation history would overwhelm the influence of shifts in aqueous chemistry.

\section{Materials and methods}

\subsection{Study site}

Samples were collected on 28 March 2016 from the parafluvial zone of the Columbia River located $80 \mathrm{~km}$ downstream of hydroelectric Priest Rapids Dam in the 300 Area of the Hanford Reach in semi-arid eastern WA, USA (Arntzen et al., 2006; Slater et al., 2010). Air temperature at the site ranged from -16 to $44^{\circ} \mathrm{C}$ in $2014-2016$ and on the day of sampling ranged from 1 to $14^{\circ} \mathrm{C}$, with a mean of $8^{\circ} \mathrm{C}$ (Hanford Meteorological Station, 2016). The site experienced trace amounts of precipitation the week before sampling and cumulative rainfall of $0.64 \mathrm{~cm}$ from 13 to 22 March (Hanford Meteorological Station, 2016). River water elevation in the Hanford Reach is controlled by dam operations and fluctuates up to $2 \mathrm{~m}$ daily (Arntzen et al., 2006). A water column pressure sensor (0-15 psig; Campbell Scientific) was used to record water level elevation and temperature near the study site at $15 \mathrm{~min}$ intervals from 2013 to 2017 . River water temperature ranged from 3.6 to $22.7^{\circ} \mathrm{C}$ in $2014-2016$ and was $6.9^{\circ} \mathrm{C}$ at the start of sample collection. Groundwater temperature, which is measured in nearby groundwater wells using the same sensor model and interval, was approximately $16.5^{\circ} \mathrm{C}$ in $2014-2016$. In order to relate shoreline elevation to historical river water elevation, an elevation survey of the study site was performed by combining manual elevation measurements with a point of known elevation for each sampling transect, which allowed for the calculation of time since last inundation by the river for each sampling elevation.

\subsection{Experimental design}

Surface sediment $(0-10 \mathrm{~cm})$ was collected at four locations along three transects (12 sites total) perpendicular to river flow and encompassing $1 \mathrm{~m}$ of elevation change (Fig. 1). The four locations were spaced laterally at $2 \mathrm{~m}$ intervals beginning at the water line and going 6 lateral meters upslope. The three transects were within $4 \mathrm{~m}$ of each other. Based on recorded river water elevation, the four sampling elevations had been last inundated by the river 0 days $(0 \mathrm{~m}$ sampling location), 13 days ( $2 \mathrm{~m}), 127$ days $(4 \mathrm{~m})$, and 398 days $(6 \mathrm{~m})$ prior to sampling. The four sampling elevations will be referred to by the time since last inundation or, for brevity, as different "histories". The highest elevations (127 and 398 days) were marked by grasses and mature trees (Morus rubra; red mulberry) with large roots extending down through the 127 days elevation. The lower elevations ( 0 and 13 days) were marked with sparse grasses and dried algal mats. All elevations had an extensive cobble layer overlying the sediment. Unsieved sediment was collected at each location for grain size analysis and for organic matter (OM) content (loss on ignition). For all remaining analyses, sediment was sieved to $<2 \mathrm{~mm}$ and subsampled in the field. Fifteenmilliliter aliquots for laboratory incubations were subsampled into $40 \mathrm{~mL}$ borosilicate incubation vials and kept on ice until used for same-day laboratory incubations. Aliquots for microbial analyses were flash-frozen in liquid $\mathrm{N}_{2}$ and kept on dry ice before storage at $-80^{\circ} \mathrm{C}$. Aliquots for $\mathrm{C} / \mathrm{N}$ (Elementar vario EL cube), sieved OM content (loss on ignition), 
and moisture content (gravimetric) were stored on dry ice before storage at $-4^{\circ} \mathrm{C}$.

\subsection{Laboratory incubations}

Pairs of incubation vials were removed from ice in a randomized order to be used for destructive sampling at 0.5 and $25 \mathrm{~h}$ time points. Sample processing and incubations were performed in a laboratory maintained at temperatures between 21 and $22{ }^{\circ} \mathrm{C}$, which correspond to maximum river temperatures. Vials were left at ambient laboratory temperature for $10 \mathrm{~min}$ before $15 \mathrm{~mL}$ of re-inundation treatment water was added to each vial, leaving a $10 \mathrm{~mL}$ headspace of ambient air. River water used for treatments was collected during sediment sampling, stored on ice, and then left at ambient laboratory temperature for approximately $1 \mathrm{~h}$ prior to use. Three replicate vials from each sample site were used per time point and were exposed to one of three different treatment waters: river water, $1: 1$ river water and synthetic $\mathrm{GW}$ without nitrate $\left(\mathrm{NO}_{3}^{-}\right)$, or $1: 1$ river water and synthetic $\mathrm{GW}$ with $\mathrm{NO}_{3}^{-}$. The lack of additional temperature control precludes comparison of our data to other work in an absolute, rather than relative or conceptual, sense. Both synthetic GW solutions were created from calcium chloride, sodium bicarbonate, magnesium sulfate, sodium sulfate, sodium carbonate, potassium carbonate, and (for $\mathrm{NO}_{3}^{-}$-containing $\mathrm{GW}$ ) calcium nitrate. The final content of each GW contained $\left(\mathrm{mmol} \mathrm{L}^{-1}\right) 1.4 \mathrm{Na}^{+}, 1.0 \mathrm{Ca}^{2+}$, $0.5 \mathrm{Mg}^{2+}, 0.2 \mathrm{~K}^{+}, 1.6 \mathrm{CO}_{3}^{2-}$, and $0.6 \mathrm{SO}_{4}^{2-}$. The $\mathrm{NO}_{3}^{-}$containing $\mathrm{GW}$ had $0.5 \mathrm{NO}_{3}^{-}$and $1.3 \mathrm{Cl}^{-}$, whereas the non- $\mathrm{NO}_{3}^{-}$ $\mathrm{GW}$ had $1.8 \mathrm{Cl}^{-}$. The final $\mathrm{pH}$ values of the three treatments were 7.59 (river water), 7.77 (river $+\mathrm{GW}$ ), and 7.66 (river $+\mathrm{GW}+\mathrm{NO}_{3}^{-}$). Vials were inverted multiple times and then stored upright (dark, ambient laboratory temperature) until their end-time sampling point.

After the incubation period, vials were shaken on a minivortex for $3 \mathrm{~min}$ to equilibrate dissolved gas with headspace. Vial headspace was subsequently sampled using a $5 \mathrm{~mL}$ gastight syringe and immediately analyzed for $\mathrm{CO}_{2}$ (EGM-4, PP Systems, Amesbury, MA, USA). $\mathrm{CO}_{2}$ values (ppm) were used as a proxy for respiration rate (RR; $\mathrm{ppm} \mathrm{CO}_{2} \mathrm{~min}^{-1} \mathrm{~g}$ dry sediment $\left.{ }^{-1}\right)$ after initial $(0.5 \mathrm{~h})$ and prolonged $(25 \mathrm{~h})$ inundation. After headspace sampling, vials were opened and subsampled. Assays on water-extracted samples included anions (Dionex ICS-2000 anion chromatograph with AS40 auto sampler), cations (nitric acid acidified; Perkin Elmer Optima 2100 DV ICP-OES with an AS93 auto sampler), pH, and dissolved non-purgeable organic carbon (NPOC; Shimadzu combustion carbon analyzer TOC-Vcsh with ASI$\mathrm{V}$ auto sampler). Ammonium $\left(\mathrm{NH}_{4}^{+}\right)$was also determined colorimetrically, following $\mathrm{KCl}$ extraction (adapted from Weatherburn, 1967) (Shimadzu UV-Vis spectrophotometer).

In addition to incubation vials that had treatment water added, a set of untreated control incubations (one from each site) was incubated for $0.5 \mathrm{~h}$ without the addition of any water, and vials were subsequently analyzed for organic acids and sugars (Agilent 1100 series HPLC), headspace $\mathrm{CO}_{2}$, and anions as described above.

\subsection{Microbial analyses}

DNA was extracted from flash-frozen sediment using a MoBio PowerSoil DNA Isolation Kit (MoBio Laboratories, Inc., Carlsbad, CA, USA) according to manufacturer's instructions with the addition of $1 \mathrm{~h}$ incubation with proteinase-K solution (Applied Biosystems, Foster City, CA, USA) and MoBio $\mathrm{C} 1$ solution to facilitate cell lysis. 16S and internal transcribed spacer (ITS) rRNA amplicon sequencing were used to identify microbial and fungal communities. Assays were performed in triplicate using an Illumina MiSeq at the Environmental Sample Preparation and Sequencing Facility at Argonne National Laboratory, Lemont, IL, USA. The recently modified forward barcoded primer set was used for 16S rRNA gene sequencing (Apprill et al., 2015), and reverse barcoded primers were used for ITS sequencing.

Quantitative polymerase chain reaction (qPCR) was used to quantify $16 \mathrm{~S}$ and ITS rRNA gene copies. Assays were performed in 384-well plates using a Life Technologies ViiA7 real-time PCR instrument at the DNA Services Facility at the University of Illinois at Chicago, using methods described previously (Nadkami et al., 2002). Final gene copies per extract were calculated by multiplying elution volume by gene abundance and were then normalized to grams of dry sediment extracted. Absolute concentrations (referred to as "abundance" throughout) of specific Operational taxonomic units (OTUs) were calculated by multiplying percent abundance from 16S rRNA gene and ITS sequencing by the sample's total bacterial, archaeal, or fungal concentration (ng $\mu \mathrm{L}^{-1} \mathrm{~g} \mathrm{dry} \mathrm{sed}^{-1}$ ) from qPCR.

\subsection{Statistical analyses}

All statistical analyses were completed using $\mathrm{R}$ (version 3.2.4). Linear and quadratic regressions were used to assess the relationship between environmental variables and $\log$ of days since inundated. If the variable clearly exhibited a stepped relationship, analysis of variance (ANOVA) and subsequent pairwise $t$ tests were used to categorically compare the elevations to each other. $R^{2}$ values reported are adjusted $R^{2}$. Significance for all analyses was determined based on $\alpha=0.05$. OTU data were rarefied for both 16S rRNA gene and ITS sequencing based on the sample with the lowest count of assigned OTUs, because assigned 16S rRNA gene OTU counts ranged from 44807 to 345 564. Rarefied data were used for all subsequent analyses, including calculation of absolute concentrations utilizing qPCR results. The chloroplast class (Chlorophyceae) was removed from 16S rRNA gene data analyses, because it is often a sequencing artifact and not indicative of sample composition. Permutational multivariate analysis of variance (PERMANOVA) and non-metric multidimensional scaling (NMDS) were used 

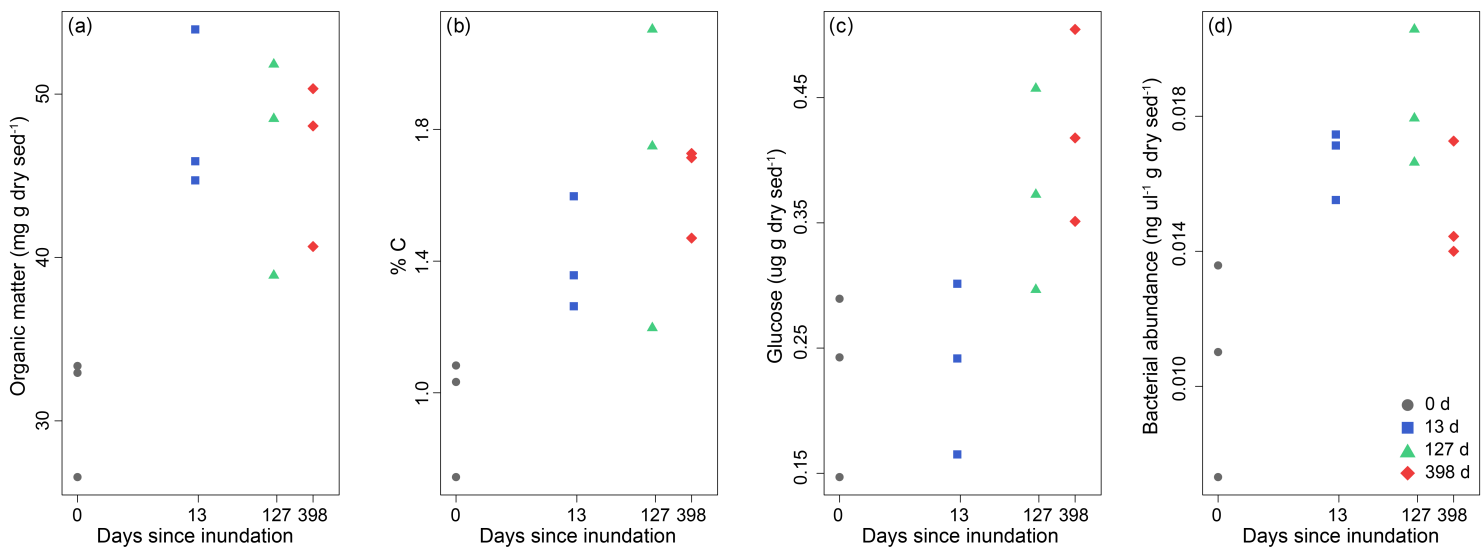

Figure 2. Environmental/microbial variables with a stepped relationship to days since inundation. All have significant categorical differences (ANOVA; $P<0.05$ for all). Note that the $x$ axis is plotted as a log scale.

to assess dissimilarities among bacterial/archaeal and fungal communities using Bray-Curtis distances calculated from 16S rRNA gene and ITS OTUs within the "vegan" R package. Significant environmental variables were plotted as vectors on NMDS plots using the "envfit" function from vegan. Because NPOC was not measured in the untreated samples, NPOC at $0.5 \mathrm{~h}$ was averaged for each sampling site to be used for statistical analyses. Linear discriminant analysis coupled with effect size (LEfSe) was performed following Niederdorfer et al. (2016). LEfSe utilizes Kruskal-Wallis sum rank tests $(\alpha=0.05)$, pairwise Wilcoxon rank-sum tests $(\alpha=0.05)$, and linear discriminant analysis (threshold $=2.0$; "all-against-all" strategy) to detect differential taxa among the four elevations and estimate effect size. Analyses were completed and figures were produced using the Huttenhower Galaxy server (http://huttenhower.sph.harvard.edu/galaxy).

\section{Results}

\subsection{Field conditions}

\subsubsection{Spatial gradients in environmental variables}

Moisture content of the sediment decreased with increasing time since last inundation, with mean (SD) percent moisture of 35.5 (6.6), 24.5 (2.2), 21.5 (1.7), and 17.5 (1.8) and mean percent field saturation $100,69,61$, and 49 , from 0,13 , 127, and 398 days, respectively. In addition, many environmental variables (OM (<2mm sieved), glucose, $\mathrm{NO}_{3}^{-}, \% \mathrm{C}$, and $\% \mathrm{~N}$ ) exhibited significant positive linear relationships with $\log$ of days since inundation (Table 1), but some variables had more complex spatial distributions linked to inundation history (Fig. 2). Specifically, OM displayed a distinct stepped relationship in which 0-day sediments had significantly lower OM than the other histories (13, 127, 398 days) (ANOVA and pairwise $t$ test; $P<0.01$ for all), and the 13-, 127-, and 398-day sediments did not differ from each other
( $P>0.7$ for all). In addition, glucose and $\% \mathrm{C}$ also exhibited stepped relationships, but in both cases, 0 days was significantly lower than only 127 and 398 days (\% C: $P<0.01$ for 127 and 398 days; glucose: $P<0.04$ for 127 and 398 days) (Fig. 2). There were no stepped relationships or significant linear relationships between log of days since inundation and $\mathrm{Cl}^{-}, \mathrm{SO}_{4}^{2-}$, or $\mathrm{NH}_{4}^{+}(P>0.05)$.

\subsubsection{Microbial biogeography}

Fungal-to-bacterial ratio, bacterial abundance, and fungal abundance were significantly positively related to log of days since inundation (Table 1). Additionally, bacterial abundance displayed a distinct stepped relationship in which 0-day sediments had significantly lower abundance than the other histories (ANOVA and pairwise $t$ test; $P<0.03$ for all), but the 13-, 127-, and 398-day sediments were not significantly different from each other $(P>0.1$ for all), much like the stepped relationships between $\log$ of days since inundation and OM, glucose, and \% C (Fig. 2).

From 16S rRNA gene and ITS sequencing, 9893 and 1856 individual OTUs were identified, respectively (Table S1 in the Supplement). The same seven fungal phyla were identified from all inundation histories with ITS sequencing. Although the order of abundance varied across the individual sites, all four inundation histories had the same top 11 bacterial and archaeal phyla identified from 16S rRNA gene sequencing (Table S2). Despite the similarities on the phylum level, the bacterial/archaeal and the fungal community compositions were significantly different across inundation history based on OTUs (PERMANOVA, bacteria/archaea: $P<0.001$; fungi: $P<0.01$ ) (Fig. 3). Of 153 bacteria/archaea classes identified by $16 \mathrm{~S}$ rRNA gene sequencing, 15 were unique to the 0-day sediments, and 2 were present at all inundation histories but absent at the 0-day sediments. Of the 15 unique classes, the most abundant were Marine Group I and South African Gold Mine Gp 1, which are both in the 

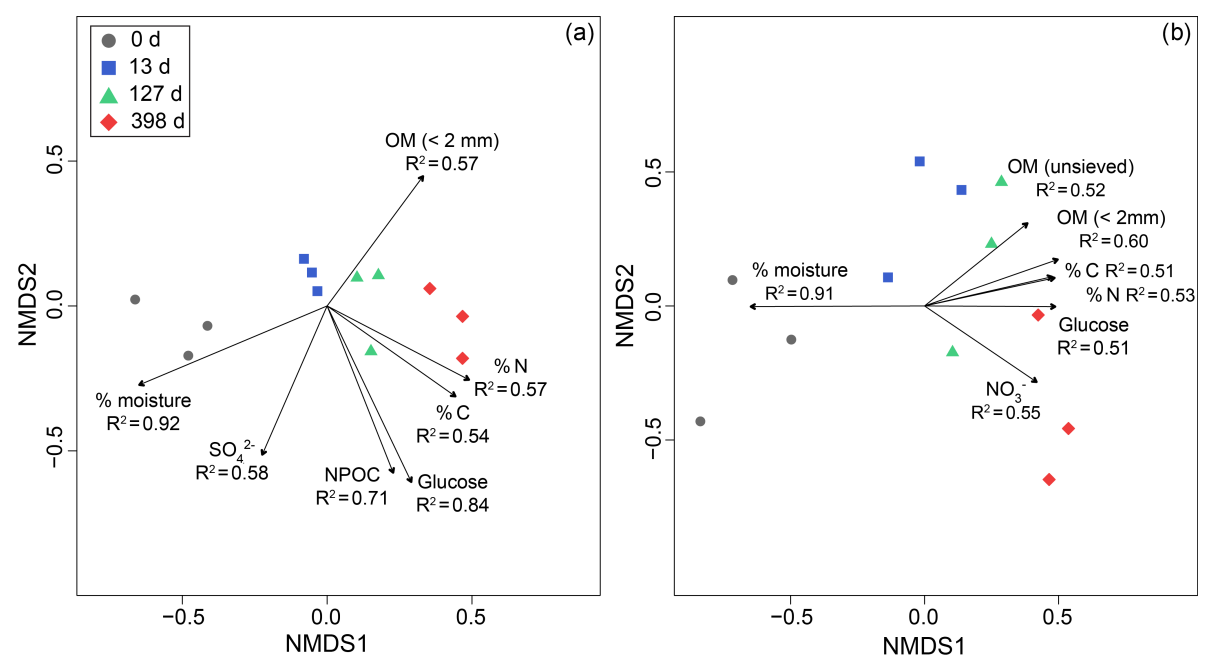

Figure 3. Non-metric multidimensional scaling (NMDS) plots of bacteria/archaea (a) and fungi (b) community composition $(n=12)$. Colors indicate groupings by days since inundation, which are significantly different (PERMANOVA, bacteria/archaea: $P<0.001$; fungi: $P<0.01$ ). Vectors indicate significant environmental variables with corresponding $R^{2}$ values.

Table 1. Mean, standard deviation (SD), significance $(P)$, and $R^{2}$ values (n.s. if not significant) from linear regressions of environmental variables and the $\log$ of days since inundation from untreated sediment $(n=12)$. Organic matter $(<2 \mathrm{~mm})$ also had a significant quadratic fit $\left(P<0.01(x) ; P=0.03\left(X^{2}\right) ; R^{2}=0.57\right)$, which is not included below. All units are per gram dry sediment.

\begin{tabular}{|c|c|c|c|c|}
\hline & Mean & SD & $P$ & $R^{2}$ \\
\hline$\%$ moisture & 24.73 & 7.49 & $<0.01$ & 0.77 \\
\hline Organic matter $(<2 \mathrm{~mm})(\mathrm{mg})$ & 42.97 & 8.56 & 0.02 & 0.41 \\
\hline Organic matter (unsieved) (mg) & 32.82 & 6.38 & 0.12 & n.s. \\
\hline Glucose $(\mu \mathrm{mol})$ & 0.32 & 0.11 & $<0.01$ & 0.53 \\
\hline Acetate $(\mu \mathrm{mol})$ & 0.88 & 1.12 & 0.22 & n.s. \\
\hline $\mathrm{NO}_{3}^{-}(\mathrm{mg})$ & 0.082 & 0.122 & 0.02 & 0.38 \\
\hline $\mathrm{NH}_{4}^{+}(\mathrm{mg})$ & 0.010 & 0.0030 & 0.93 & n.s. \\
\hline$\% \stackrel{4}{\mathrm{C}}$ & 1.42 & 0.38 & $<0.01$ & 0.54 \\
\hline$\% \mathrm{~N}$ & 0.14 & 0.038 & $<0.01$ & 0.55 \\
\hline $\mathrm{C} / \mathrm{N}$ & 9.89 & 0.47 & 0.87 & n.s. \\
\hline Fungal-to-bacterial ratio & 0.058 & 0.041 & 0.01 & 0.43 \\
\hline Fungal biomass (ng $\left.\mu \mathrm{L}^{-1}\right)$ & 0.015 & 0.0035 & 0.01 & 0.42 \\
\hline Bacterial biomass (ng $\mu \mathrm{L}^{-1}$ ) & $9.4 \times 10^{-4}$ & $7.70 \times 10^{-4}$ & 0.03 & 0.32 \\
\hline Archaeal biomass (ng $\left.\mu \mathrm{L}^{-1}\right)$ & $1.1 \times 10^{-4}$ & $6.9 \times 10^{-5}$ & 0.85 & n.s. \\
\hline
\end{tabular}

ammonia-oxidizing Thaumarchaeota phylum (Francis et al., 2005; Brochier-Armanet et al., 2008). Additionally, LEfSe identified no archaeal, no fungal, and 12 bacterial taxa driving dissimilarity among the inundation histories (Fig. S1 in the Supplement). All of the LEfSe-identified taxa were from the 0 - and 398-day sediments.

Bacterial/archaeal and fungal communities clustered in distinct inundation history groups in NMDS plots (stress $=0.01$ and 0.04 , respectively; Fig. $3 \mathrm{a}$ and b). Significant environmental variables plotted as vectors on NMDS plots indicate moisture content was the strongest predictor of both bacterial/archaeal and fungal communities, with the 0 -day sediments clustering separately from the other inunda- tion histories and $R^{2}$ for moisture of 0.90 and 0.91 , respectively (envfit). Carbon was a significant explanatory variable in both communities in multiple forms (e.g., \% $\mathrm{C}, \mathrm{OM}$, glucose, $\mathrm{NPOC})$. Additionally, $\% \mathrm{~N}, \mathrm{SO}_{4}^{2-}$, and $\mathrm{NO}_{3}^{-}$were significant for one or both communities and are displayed as vectors (Fig. 3a and b).

\subsection{Incubations}

\subsubsection{Response to different treatment waters}

The initial $(0.5 \mathrm{~h})$, prolonged $(25 \mathrm{~h})$, or change $(25-0.5 \mathrm{~h})$ in any measured inundation response (respiration rate, NPOC, cations, anions) did not differ significantly across treatment 

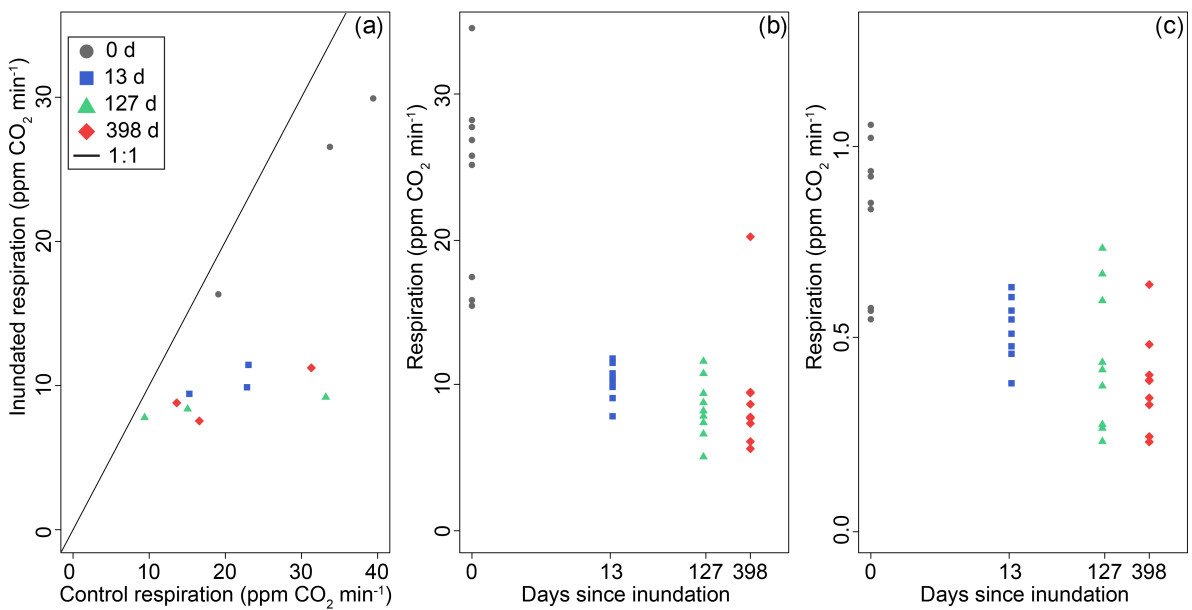

Figure 4. RR of untreated control samples and $0.5 \mathrm{~h}$ inundated samples with black $1: 1$ line (a), $0.5 \mathrm{~h}$ inundated RR and days since inundation (b), and $25 \mathrm{~h} \mathrm{RR}$ and days since inundation (c). Note that in (a) 0 days since inundation RR (gray) plots along $1: 1$ line, but upper-elevation inundated RR does not co-vary with uninundated RR. Note that in (b) and (c) the $x$ axis is plotted as a log scale.

Table 2. Nitrate concentrations from untreated sediment (mean and standard deviation; uncorrected for grams of dry sediment) and nitrate and anion concentrations from treatment water.

\begin{tabular}{|c|c|c|c|c|c|}
\hline & $\mathrm{NO}_{3}^{-}\left(\mathrm{mg} \mathrm{L}^{-1}\right)$ & $\mathrm{Na}^{+}\left(\mathrm{mg} \mathrm{L}^{-1}\right)$ & $\mathrm{Ca}^{2+}\left(\mathrm{mg} \mathrm{L}^{-1}\right)$ & $\mathrm{Mg}^{2+}\left(\mathrm{mg} \mathrm{L}^{-1}\right)$ & $\mathrm{K}^{+}\left(\mathrm{mg} \mathrm{L}^{-1}\right)$ \\
\hline River water treatment & 1.75 & 4.16 & 19.85 & 5.07 & 1.05 \\
\hline Groundwater without $\mathrm{NO}_{3}^{-}$treatment & 0.70 & 18.35 & 29.80 & 8.70 & 3.83 \\
\hline \multirow[t]{2}{*}{ Groundwater with $\mathrm{NO}_{3}^{-}$treatment } & 14.49 & 18.14 & 30.91 & 8.54 & 4.28 \\
\hline & $\mathrm{NO}_{3}^{-}\left(\mathrm{mg} \mathrm{L}^{-1}\right)$ & SD & & & \\
\hline 0 -day sediment & 1.17 & 0.69 & & & \\
\hline 13-day sediment & 3.43 & 3.67 & & & \\
\hline 127-day sediment & 18.49 & 6.61 & & & \\
\hline 398-day sediment & 64.81 & 48.30 & & & \\
\hline
\end{tabular}

waters (river water; $1: 1$ river water and synthetic $\mathrm{GW}$ without $\mathrm{NO}_{3}^{-} ; 1: 1$ river water and synthetic $\mathrm{GW}$ with $\mathrm{NO}_{3}^{-}$) (ANOVA: $P>0.05$ ) (Table S3), despite the large differences in $\mathrm{NO}_{3}^{-}$between treatments and source sediment and the differing cation contents of the treatment waters (Table 2). Given the lack of treatment effect, the results from the three treatments were pooled and utilized as replicates for all other incubation-based results.

\subsubsection{Respiration response to inundation}

In control sediment (no water added), RR across all inundation histories was not significantly different (ANOVA; $P>0.2$ ). Although initial and prolonged inundation suppressed RR relative to control sediment across all inundation histories, the degree of suppression was dramatically different between 0-day sediments and the other histories (Fig. 4). Specifically, following experimental inundation, the samples that had been saturated at the time of sediment collection (0-day sediments) had a significantly higher RR than those unsaturated at the time of sediment collection $(13,127$, 398 days) (ANOVA and pairwise $t$ test; $P<0.001$ ), and the 13-, 127-, and 398-day sediments did not have RRs significantly different from each other (pairwise $t$ test; $P>0.07$ ) (Fig. 4b, c). Across the inundation histories, therefore, the RR response to inundation was binary, with greater suppression relative to uninundated rates in the sediments with greater times since last inundation and the highest RR in 0 day sediments.

\section{Discussion}

\subsection{Microbial respiration response to inundation}

The RR suppression in the 13-, 127-, and 398-day sediments relative to the 0 -day sediments after both initial and prolonged inundation (Fig. 4a, b, c) indicates that brief increases in moisture content (e.g., recurring splashing or $<1$ day periods of hydropeaking) can suppress respiration rates in the parafluvial hyporheic zone. Numerous studies have re- 


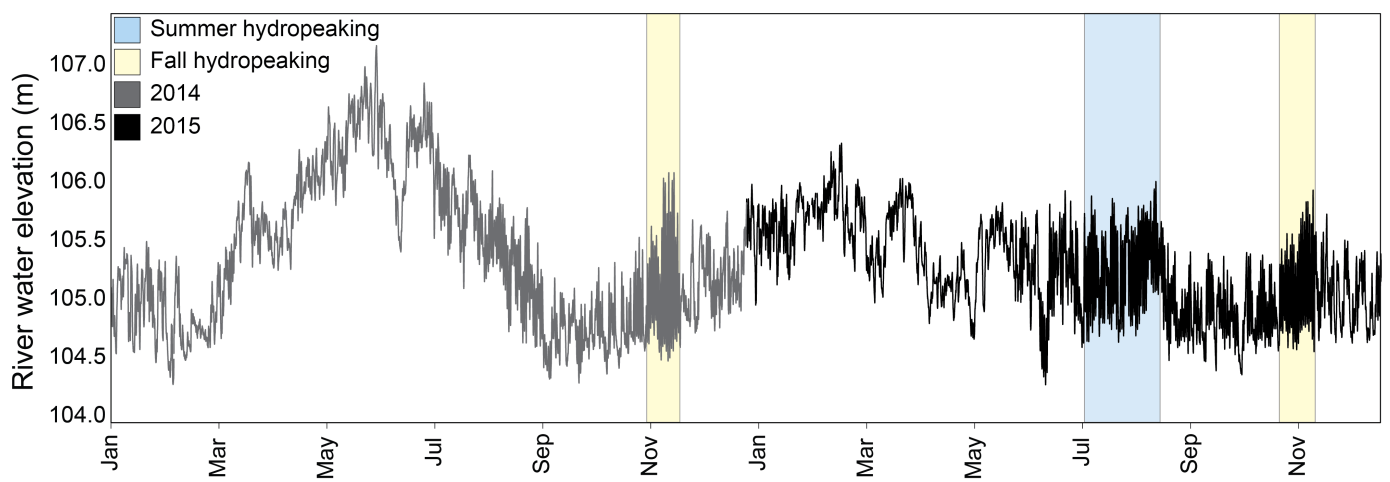

Figure 5. River water elevation near the study site, 2014 through 2015. Note that melting snowpack caused an increase in water elevation during the spring of 2014. In 2015, the lack of spring water elevation rise was due to very little snowpack in the winter, which then led to increased hydropeaking in the summer of 2015 that is not seen in 2014 and is typically only seen in late fall.

ported high $\mathrm{CO}_{2}$ production when dry soils are wetted (e.g., the Birch effect; Birch, 1958; Fierer and Schimel, 2003) and greater $\mathrm{CO}_{2}$ from soils undergoing wet-dry cycles than those maintained at a specific moisture content (Miller et al., 2005). We therefore had hypothesized that high amounts of carbon (\% C, glucose, NPOC, OM) and bacterial abundance would fuel respiration in the samples unsaturated during sediment collection $(13,127,398$ days) immediately following forced inundation, despite the sediments being at $49-69 \%$ field saturation; however, we found that, prior to forced inundation, RR did not differ significantly across 13-, 127-, and 398-day sediments but that after inundation the sediments had significantly lower RR than 0-day sediments. Consistent RR across 13-, 127-, and 398-day sediments was unexpected, because they differed significantly in features that influence RR, including microbial composition, surrounding vegetation, and time since most recent river inundation. We suggest that microbial communities in sediments that are inundated permanently or for extended periods are better adapted to full water saturation than those that are infrequently inundated, which led to the binary RR response between 0 -day sediments and the other inundation histories. This finding is similar to that of Hawkes et al. (2017), who reported that historically wetter soil emitted twice as much carbon, on average, than historically drier soils.

The RR suppression within the 13-, 127-, and 398-day sediments following re-inundation could be attributed to multiple factors. First, the bacterial communities may have physiologically adapted to prolonged terrestrial conditions, and the sudden return to aquatic conditions may have led to osmotic shock or another stress response that produced a lower RR than that of the already saturated samples (0-day sediments) (Kieft et al., 1987; Fierer et al., 2003; Jarvis et al., 2007; Schimel et al., 2007; Borken and Matzner, 2009; Warren, 2014; Meisner et al., 2015). Second, the microbial community composition may have been less suited to respiring carbon in aquatic conditions or during wet-dry cycles specifically due to the higher proportion of fungi (Lundquist et al., 1999). Fungi have been shown to account for the majority of soil/sediment respiration, with variability across studies yielding estimates of respiration contribution of $78 \%$ (Anderson and Domsch, 1973), 74-90\% (Blagodatskaya and Anderson, 1998), and 18-40\% (Sapronov and Kuzyakov, 2007). As filamentous fungi are poorly adapted to soils/sediments that are water-saturated or inundated for extended periods (Alexander, 1977; Kominkova et al., 2000; Kuehn et al., 2000), it follows that, for sediment that experiences less frequent inundation, microbial respiration will be depressed upon re-inundation due to fungal suppression.

Both scenarios may have contributed to the RR response to inundation, but an osmolytic microbial stress response was unlikely considering the relatively high moisture content of the sediments prior to forced inundation. Given the expected fungal response to inundation and the higher proportion of fungi in the sediments unsaturated at the time of sampling, it is most likely that community composition - in particular the fungal-to-bacterial ratio - was a key driver to the RR response. The persistence of the RR spatial distribution after prolonged inundation further suggests a significant time lag in the response of the 13-, 127-, and 398-day sediments following perturbation, which can be attributed to the need for community shifts in response to inundation.

Within the context of the historically contingent responses to re-inundation, the absence of re-inundation response differences among the three treatment waters suggests that inundation history is a stronger driver of short-term biogeochemical dynamics than shifts in aquatic chemistry. Large fluctuations in river water elevation alter hydraulic flow paths at the study site (Arntzen et al., 2006) and subsequently determine whether surface sediments are exposed to river water, bank storage of river water altered by hyporheic biogeochemical transformation (Wörman et al., 2002), or GW flowing out to the river through the hyporheic zone (Boano et al., 2008). The treatment waters were intended to reflect 
the range of aqueous chemistry conditions resulting from the exposure to these different water sources. The lack of difference among the treatment waters was unexpected, particularly for $\mathrm{NO}_{3}^{-}$. In the sediments with greater time since last inundation where $\mathrm{NO}_{3}^{-}$was highest (Table 2), the sediment values likely overwhelmed the influence of the $\mathrm{NO}_{3}^{-}$treatment, but this should not have been the case for the more recently inundated sediments, where we expected reduction of $\mathrm{NO}_{3}^{-}$and potentially associated production of $\mathrm{NO}_{2}^{-}$or $\mathrm{NH}_{4}^{+}$. Locations with longer times since inundation accumulated more biogeochemically reactive water soluble analytes (e.g., $\mathrm{NO}_{3}^{-}$, glucose) that would not have suppressed RR upon re-inundation; if anything, we would expect them to stimulate RR. This, combined with lack of response to experimental treatments, strongly suggests that the influence of inundation history is via the microbial community. In this case, non-inundated conditions select for a suite of traits that allow for growth and reproduction under relatively dry to moist conditions, with the apparent tradeoff of metabolic suppression upon re-inundation. As such, we propose that inundation history influences short-term biogeochemical responses to re-inundation by imposed ecological selection for traits that fall along a tradeoff surface that spans fungal and bacterial/archaeal strategies. This is similar to Chambers et al. (2016), who reported greater impacts on microbial community structure and function from inundation history relative to water chemistry (salinity) in mangrove peat soil.

\subsection{Microbial communities differ along inundation history gradient}

Examining patterns of microbial community structure and relative abundances of fungi and bacteria across the inundation histories provides evidence in support of inundation history influencing biogeochemical responses via selection for locally adapted microbial communities. In the 0-day sediments, the fungal-to-bacterial ratio and the abundance of fungi were lower than those in the sediments that experienced longer periods of unsaturated conditions. Other studies have identified similar patterns in which the ratio of fungal to bacterial biomass, based upon phospholipid fatty acid (PLFA) biomarkers, was consistently lower in flooded vs. unsaturated soil (Bossio et al., 1998), and the fungal biomarker $18: 2 \omega 6,9 \mathrm{c}$ was absent in in long-term submerged floodplain soil relative to floodplain soils experiencing shorter inundation time (Rinklebe and Langer, 2006). With regard to bacteria, LEfSe only identified bacterial taxa driving dissimilarity from 0- and 398-day sediments (Fig. S1), which suggests that there was a gradient in bacterial community composition in which the two inundation history end-members paired with community end-members. Therefore, inundation history likely drove the spatial distribution of microbial community composition, which supports the inference that the response to re-inundation was influenced by the specific com-
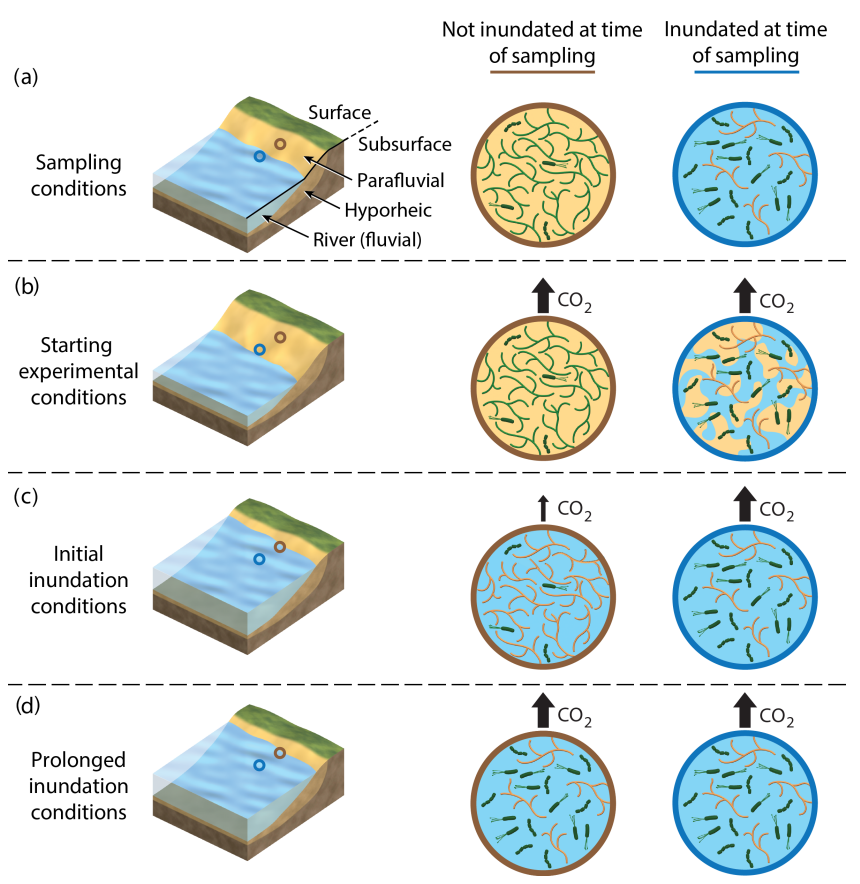

Figure 6. Illustration of field conditions during sampling (a) and of incubation conditions prior to experimental inundation (b), during initial inundation (c), and following prolonged inundation (d). River elevation diagrams (far left) display field conditions replicated by the incubation experiments. In historically uninundated sediments (middle), fungi (branching organisms) perform well (green) (a, b) but are metabolically suppressed (orange) upon initial re-inundation (blue shading), leading to lower $\mathrm{CO}_{2}$ flux (thin arrow) (c). We propose that prolonged inundation shifts the community towards bacterial (rod shapes) dominance, leading to an eventual recovery of $\mathrm{CO}_{2}$ flux (thick arrow) (d). In historically inundated sediments (far right), bacteria perform well and maintain a higher $\mathrm{CO}_{2}$ flux both during a brief drop in river stage in which the sediments lack an overlying water column but stay saturated (b) and when water level rises $(\mathbf{c}, \mathbf{d})$.

munity makeup (e.g., proportion of fungi, bacterial community differences).

\subsection{Implications of parafluvial hydrobiogeochemical processes for predictive models}

Biogeochemical response lags due to physiological stress of parafluvial microbial communities are of particular importance in creating modeling frameworks that can accurately predict the biogeochemical behavior of terrestrial-aquatic transition zones in managed systems. Our results indicate that a combination of ecological and physiological mechanisms limited the ability of the microbial communities to rapidly adapt to an inundated state. This resulted in the suppression of RR, which we propose is a transient condition whereby there is also temporal lag in biogeochemical function. A long time lag is often observed in microbial adaptation to the abrupt change in local environment 
(Wood et al., 1995). This phenomenon can affect the transport of biodegradable substrates and contaminants, particularly when the timescale of the metabolic lag is comparable to that of transport (Nilsen et al., 2012). Despite such importance, mechanistic approaches for incorporating metabolic lags into subsurface transport modeling are currently lacking. Past modeling work that attempted to account for this lag effect either was based on a temporal convolution integral (Wood et al., 1995; Nilsen et al., 2012) or introduced exposure time as an additional dimension (or coordinate) (Ginn, 1999). These efforts do not address fundamental mechanisms responsible for time lags, and consequently their predictions may be limited. Given that we find time lags to be extremely important to the microbial and biogeochemical behavior of our system, future modeling efforts need to consider more ecologically and physiologically relevant causes for delays in microbial adaption and associated biogeochemical function, including the response to changes in timing and magnitude of flow variations.

The need for models that can incorporate the microbial response to changes in flow variation is particularly important in the context of climate-watershed interactions. In years with low snowpack, the degree of short-term stage fluctuations (hydropeaking) through the summer is significantly elevated (Fig. 5). Local inundation dynamics (e.g., frequency of inundation) are therefore sensitive to watershed hydrology even in highly managed main-stem river corridor systems, and the influences should be even stronger in lower-order and unmanaged streams that are subject to direct environmental flows regimes without the regulating influence of dams. Therefore, in watersheds that are projected to shift from snowpack- to rain-dominated hydrology, like those found in the US Pacific Northwest, prediction of biogeochemical responses to changes in inundation dynamics is needed. Filling this knowledge gap is urgent, not only given the global expansion of hydropower, with 3700 large dams planned worldwide as of 2015 (Zarfl et al., 2015), but also because of its widespread applicability to naturally variable systems (e.g., intermittent streams, unregulated rivers, tidally influenced littoral zones of the Great Lakes).

\section{Conclusions}

From the synthesis of our results, we have derived the following conceptual model (Fig. 6): watershed-climate interactions lead to changes in river elevation fluctuations, which alter parafluvial inundation dynamics (e.g., magnitude and time between inundation events). Irregular hydrologic fluctuations create spatial variation in the concentrations of $\mathrm{C}$ and $\mathrm{N}$ reactants and microbial communities adapted to local conditions (i.e., increasing fungal populations with increasing time since inundation) (Fig. 6a). Under conditions that allow for local adaptation, there is a relatively high flux of $\mathrm{CO}_{2}$ from microbial respiration (Fig. 6b). Upon re-inundation
(Fig. 6c, middle), substrates become more available for use, but microbial communities are initially suppressed metabolically because they are adapted to unsaturated conditions (e.g., rapid transport and significant penetration of oxygen into sediment due to gas-filled pore spaces). The result is lower $\mathrm{CO}_{2}$ flux rates primarily due, we hypothesize, to suppression of fungal respiration. Following prolonged inundation, the microbial community should adapt via a shift in composition away from fungal dominance (Fig. 6d). The timescales of such responses are an important knowledge gap and may depend upon the time since inundation. Ultimately, local adaptation to an inundated state should lead to recovery of pre-inundation $\mathrm{CO}_{2}$ flux rates, but the timescale of adaptation is unclear. This conceptual model hypothesizes that biogeochemical functions (i.e., $\mathrm{CO}_{2}$ flux rates) are resilient in the sense that they recover to pre-disturbance conditions. The degree to which this occurs, the associated timescales, and the dependence of "biogeochemical resilience" on historical and ongoing inundation dynamics are important, open questions.

The Columbia River is one of many high-order rivers with an extensive alluvial hyporheic zone (Downing et al., 2012). Our results can therefore be applicable not only to other regions along the Columbia River but also to other rivers worldwide. We demonstrate that biogeochemical cycling in the parafluvial zone does not follow behavior commonly observed in soils and sediments, wherein rewetting produces a pulse of $\mathrm{CO}_{2}$, and that inundation history influences the ability of parafluvial hyporheic microbial communities to respond to re-inundation. In addition to causing spatial variation in the concentrations of key reactants within $\mathrm{C}$ and $\mathrm{N}$ cycles, inundation history along the parafluvial zone affects aquatic-terrestrial biogeochemical cycling by driving variation in microbial community composition that, in turn, governs biogeochemical responses to hydrologic perturbation. The parafluvial hyporheic zone should therefore be considered as an important ecotone for biogeochemical dynamics and may need to be integrated as a distinct environment within hydrobiogeochemical models to predict the watershed biogeochemical function. Future research would benefit from studying other dam-influenced systems as well as seasonal influences to support widespread applicability.

Data availability. Data are accessible at https://osf.io/ sz4d7/ Goldman_et_al_2017_Data.zip, Goldmanet al., https://doi.org/10.17605/OSF.IO/SZ4D7).
The Supplement related to this article is available online at https://doi.org/10.5194/bg-14-4229-2017-supplement. 
Author contributions. AEG, EBG, ARC, DWK, and JCS contributed to experimental design. AEG, EBG, ARC, DWK, EBR, CGA, KLD, CTR, and JKF contributed to sample collection and analysis. AEG, EBG, ARC, DWK, JKF, and JCS contributed to data interpretation. AEG prepared manuscript with contributions from all authors.

Competing interests. The authors declare that they have no conflict of interest.

Acknowledgements. Thank you to Mike Perkins for the Fig. 6 graphic; Hyun-Seob Song for modeling expertise; and Eric Bottos, Taniya Roy Chowdhury, Yukari Maezato, and Tom Wietsma for sample analysis. This research was supported by the US Department of Energy (DOE), Office of Biological and Environmental Research (BER), as part of the Subsurface Biogeochemical Research Program's Scientific Focus Area (SFA) at the Pacific Northwest National Laboratory (PNNL). PNNL is operated for DOE by Battelle Memorial Institute under contract DE-AC0676RLO 1830.

Edited by: Clare Woulds

Reviewed by: two anonymous referees

\section{References}

Alexander, M.: Introduction to soil microbiology, 2 Edn., John Wiley \& Sons, 1977.

Anderson, J. P. E. and Domsch, K. H.: Quantification of bacterial and fungal contributions to soil respiration, Archiv für Mikrobiologie, 93, 113-127, https://doi.org/10.1007/bf00424942, 1973.

Apprill, A., McNally, S., Parsons, R., and Webe, L.: Minor revision to V4 region SSU rRNA 806R gene primer greatly increases detection of SAR11 bacterioplankton, Aquat. Microb. Ecol., 75, 129-137, https://doi.org/10.3354/ame01753 2015.

Arntzen, E. V., Geist, D. R., and Dresel, P. E.: Effects of fluctuating river flow on groundwater/surface water mixing in the hyporheic zone of a regulated, large cobble bed river, RRA, 22, 937-946, https://doi.org/10.1002/rra.947, 2006.

Baker, M. A., Dahm, C. N., and Valett, H. M.: Acetate retention and metabolism in the hyporheic zone of a mountain stream, Limnol. Oceanogr., 44, 1530-1539, https://doi.org/10.4319/lo.1999.44.6.1530, 1999.

Birch, H.: The effect of soil drying on humus decomposition and nitrogen availability, Plant Soil, 10, 9-31, https://doi.org/10.1007/BF01343734, 1958.

Blagodatskaya, E. V. and Anderson, T.-H.: Interactive effects of $\mathrm{pH}$ and substrate quality on the fungal-to-bacterial ratio and $q \mathrm{CO}_{2}$ of microbial communities in forest soils, Soil Biol. Biochem., 30, 1269-1274, https://doi.org/10.1016/S0038-0717(98)000509, 1998.

Boano, F., Revelli, R., and Ridolfi, L.: Reduction of the hyporheic zone volume due to the stream-aquifer interaction, GeoRL, 35, 1-5, https://doi.org/10.1029/2008GL033554, 2008.

Bodmer, P., Freimann, R., von Fumetti, S., Robinson, C. T., and Doering, M.: Spatio-temporal relationships between habitat types and microbial function of an upland floodplain, Aquat. Sci., 78 , 241-254, https://doi.org/10.1007/s00027-015-0420-9, 2016.

Borken, W. and Matzner, E.: Reappraisal of drying and wetting effects on $\mathrm{C}$ and $\mathrm{N}$ mineralization and fluxes in soils, Global Change Biol., 15, 808-824, https://doi.org/10.1111/j.13652486.2008.01681.x, 2009.

Bossio, D. A., Scow, K. M., Gunapala, N., and Graham, K.: Determinants of soil microbial communities: effects of agricultural management, season, and soil type on phospholipid fatty acid profiles, MicEc, 36, 1-12, https://doi.org/10.1007/s002489900087, 1998.

Boulton, A. J., Findlay, S., Marmonier, P., Stanley, E. H., and Valett, H. M.: The Functional Significance of the Hyporheic Zone in Streams and Rivers, Annu. Rev. Ecol. Syst., 29, 59-81, https://doi.org/10.1146/annurev.ecolsys.29.1.59, 1998.

Boulton, A. J., Datry, T., Kasahara, T., Mutz, M., and Stanford, J. A.: Ecology and management of the hyporheic zone: streamgroundwater interactions of running waters and their floodplains, J. N. Am. Benthol. Soc., 29, 26-40, https://doi.org/10.1899/08017.12010.

Briody, A. C., Cardenas, M. B., Shuai, P., Knappett, P. S. K., and Bennett, P. C.: Groundwater flow, nutrient, and stable isotope dynamics in the parafluvial-hyporheic zone of the regulated Lower Colorado River (Texas, USA) over the course of a small flood, HydJ, 24, 923-935, https://doi.org/10.1007/s10040-016-1365-3, 2016.

Brochier-Armanet, C., Boussau, B., Gribaldo, S., and Forterre, P.: Mesophilic crenarchaeota: proposal for a third archaeal phylum, the Thaumarchaeota, Nat. Rev. Microbiol., 6, 245-252, https://doi.org/10.1038/nrmicro1852, 2008.

Burns, A. and Ryder, D. S.: Response of bacterial extracellular enzymes to inundation of floodplain sediments, Freshwater Biol., 46, 1299-1307, https://doi.org/10.1046/j.13652427.2001.00750.x, 2001.

Chambers, L. G., Guevara, R., Boyer, J. N., Troxler, T. G., and Davis, S. E.: Effects of Salinity and Inundation on Microbial Community Structure and Function in a Mangrove Peat Soil, Wetlands, 36, 361-371, https://doi.org/10.1007/s13157016-0745-8, 2016.

Claret, C. and Boulton, A. J.: Integrating hydraulic conductivity with biogeochemical gradients and microbial activity along rivergroundwater exchange zones in a subtropical stream, HydJ, 17, 151-160, https://doi.org/10.1007/s10040-008-0373-3, 2008.

Deforet, T., Marmonier, P., Rieffel, D., Crini, N., Giraudoux, P., and Gilbert, D.: Do parafluvial zones have an impact in regulating river pollution? Spatial and temporal dynamics of nutrients, carbon, and bacteria in a large gravel bar of the Doubs River (France), Hydrobiologia, 623, 235-250, https://doi.org/10.1007/s10750-008-9661-0, 2009.

Doering, M., Uehlinger, U. R. S., Ackermann, T., Woodtli, M., and Tockner, K.: Spatiotemporal heterogeneity of soil and sediment respiration in a river-floodplain mosaic (Tagliamento, NE Italy), Freshwater Biol., 56, 1297-1311, https://doi.org/10.1111/j.13652427.2011.02569.x, 2011.

Downing, J. A., Cole, J. J., Duarte, C. A., Middelburg, J. J., Melack, J. M., Prairie, Y. T., Kortelainen, P., Striegl, R. G., McDowell, W. H., and Tranvik, L. J.: Global abundance and size distribution of streams and rivers, Inland waters, 2, 229-236, https://doi.org/10.5268/IW-2.4.502, 2012. 
Fierer, N. and Schimel, J. P.: A proposed mechanism for the pulse in carbon dioxide production commonly observed following the rapid rewetting of a dry soil, SSSAJ, 67, 798-805, https://doi.org/10.2136/sssaj2003.7980, 2003.

Fierer, N., Schimel, J. P., and Holden, P. A.: Influence of DryingRewetting Frequency on Soil Bacterial Community Structure, MicEc, 45, 63-71, https://doi.org/10.1007/s00248-002-1007-2, 2003.

Francis, C. A., Roberts, K. J., Beman, J. M., Santoro, A. E., and Oakley, B. B.: Ubiquity and diversity of ammoniaoxidizing archaea in water columns and sediments of the ocean, Proc. Natl. Acad. Sci. USA, 102, 14683-14688, https://doi.org/10.1073/pnas.0506625102 2005.

Ginn, T. R.: On the distribution of multicomponent mixtures over generalized exposure time in subsurface flow and reactive transport: Foundations, and formulations for groundwater age, chemical heterogeneity, and biodegradation, Water Resour. Res., 35, 1395-1407, https://doi.org/10.1029/1999WR900013, 1999.

Goldman, A. E., Graham, E. B., Crump, A. R., Kennedy, D. W., Romero, E. B., Anderson, C. G., Dana, K. L., Resch, C. T., Fredrickson, J. K., and Stegen, J. C.: Goldman_et_al_2017_Data.zip, Open Science Framework, https://doi.org/10.17605/OSF.IO/SZ4D7, https://osf.io/sz4d7/, last access: 18 September 2017.

Graham, E. B., Crump, A. R., Resch, C. T., Fansler, S., Arntzen, E., Kennedy, D. W., Fredrickson, J. K., and Stegen, J. C.: Coupling Spatiotemporal Community Assembly Processes to Changes in Microbial Metabolism, Front. Microbiol., 7, 1-13, https://doi.org/10.3389/fmicb.2016.01949, 2016.

Graham, E. B., Crump, A. R., Resch, C. T., Fansler, S., Arntzen, E., Kennedy, D. W., Fredrickson, J. K., and Stegen, J. C.: Deterministic influences exceed dispersal effects on hydrologicallyconnected microbiomes, Environ. Microbiol., 19, 1552-1567, https://doi.org/10.1111/1462-2920.13720, 2017.

Hanford Meteorological Station, March 2016 Historical Weather Chart, http://www.hanford.gov/files.cfm/Mar2016.pdf, last: access: 20 November 2016.

Hawkes, C. V., Waring, B. G., Rocca, J. D., and Kivlin, S. N.: Historical climate controls soil respiration responses to current soil moisture, Proc. Natl. Acad. Sci. USA, 114, 6322-6327, https://doi.org/10.1073/pnas.1620811114, 2017.

Hermoso, V.: Freshwater ecosystems could become the biggest losers of the Paris Agreement, Glob. Change Biol., 23, 34333436, https://doi.org/10.1111/gcb.13655, 2017.

Hucks Sawyer, A., Bayani Cardenas, M., Bomar, A., and Mackey, M.: Impact of dam operations on hyporheic exchange in the riparian zone of a regulated river, Hydrol. Proc., 23, 2129-2137, https://doi.org/10.1002/hyp.7324, 2009.

Hupp, C. R. and Osterkamp, W. R.: Riparian vegetation and fluvial geomorphic processes, Geomorphology, 14, 277-295, https://doi.org/10.1016/0169-555X(95)00042-4, 1996.

Jackson, R. B., Carpenter, S. R., Dahm, C. N., McKnight, D. M., Naiman, R. J., Postel, S. L., and Running, S. W.: Water in a changing world, Ecol. Appl., 11, 1027-1045, https://doi.org/10.1890/10510761(2001)011[1027:WIACW]2.0.CO;2, 2001.

Jarvis, P., Rey, A., Petsikos, C., Wingate, L., Rayment, M., Pereira, J., Banza, J., David, J., Miglietta, F., Borghetti, M., Manca, G., and Valentini, R.: Drying and wetting of Mediterranean soils stimulates decomposition and carbon dioxide emission: The "Birch effect", Tree Physiol., 27, 929-940, 2007.

Kieft, T. L., Soroker, E., and Firestone, M. K.: Microbial biomass response to a rapid increase in water potential when dry soil is wetted, Soil Biol. Biochem., 19, 119-126, https://doi.org/10.1016/0038-0717(87)90070-8, 1987.

Kim, D. G., Vargas, R., Bond-Lamberty, B., and Turetsky, M. R.: Effects of soil rewetting and thawing on soil gas fluxes: A review of current literature and suggestions for future research, Biogeosciences, 9, 2459-2483, https://doi.org/10.5194/bg-9-24592012, 2012.

Kominkova, D., Kuehn, K. A., Busing, N., Steiner, D., and Gessner, M. O.: Microbial biomass, growth, and respiration associated with submerged litter of Phragmites australis decomposing in a littoral reed stand of a large lake, Aquat. Microb. Ecol., 22, 271-282, https://doi.org/10.3354/ame022271 2000.

Kuehn, K. A., Lemke, M. J., Suberkropp, K., and Wetzel, R. G.: Microbial biomass and production associated with decaying leaf litter of the emergent macrophyte Juncus effusus, Limnol. Oceanogr., 45, 862-870, https://doi.org/10.4319/lo.2000.45.4.0862, 2000.

Larned, S. T., Datry, T., Arscott, D. B., and Tockner, K.: Emerging concepts in temporary-river ecology, Freshwater Biol., 55, 717738, https://doi.org/10.1111/j.1365-2427.2009.02322.x, 2010.

Latrubesse, E. M., Arima, E. Y., Dunne, T., Park, E., Baker, V. R., d'Horta, F. M., Wight, C., Wittmann, F., Zuanon, J., Baker, P. A., Ribas, C. C., Norgaard, R. B., Filizola, N., Ansar, A., Flyvbjerg, B., and Stevaux, J. C.: Damming the rivers of the Amazon basin, Natur, 546, 363-369, https://doi.org/10.1038/nature22333, 2017.

Leigh, C., Boulton, A. J., Courtwright, J. L., Fritz, K., May, C. L., Walker, R. H., and Datry, T.: Ecological research and management of intermittent rivers: an historical review and future directions, Freshwater Biol., 61, 1181-1199, https://doi.org/10.1111/fwb.12646, 2016.

Lundquist, E. J., Scow, K. M., Jackson, L. E., Uesugi, S. L., and Johnson, C. R.: Rapid response of soil microbial communities from conventional, low input, and organic farming systems to a wet/dry cycle, Soil Biol. Biochem., 31, 1661-1675, https://doi.org/10.1016/S0038-0717(99)00080-2, 1999.

McClain, M. E., Boyer, E. W., Dent, C. L., Gergel, S. E., Grimm, N. B., Groffman, P. M., Hart, S. C., Harvey, J. W., Johnston, C. A., and Mayorga, E.: Biogeochemical hot spots and hot moments at the interface of terrestrial and aquatic ecosystems, Ecosystems, 6, 301-312, https://doi.org/10.1007/s10021-003-0161-9, 2003.

Meisner, A., Rousk, J., and Bååth, E.: Prolonged drought changes the bacterial growth response to rewetting, Soil Biol. Biochem., 88, 314-322, https://doi.org/10.1016/j.soilbio.2015.06.002, 2015.

Miller, A. E., Schimel, J. P., Meixner, T., Sickman, J. O., and Melack, J. M.: Episodic rewetting enhances carbon and nitrogen release from chaparral soils, Soil Biol. Biochem., 37, 2195-2204, https://doi.org/10.1016/j.soilbio.2005.03.021, 2005.

Mulholland, P. J. and Webster, J. R.: Nutrient dynamics in streams and the role of J-NABS, J. N. Am. Benthol. Soc., 29, 100-117, https://doi.org/10.1899/08-035.1, 2010.

Nadkami, M. A., Martin, F. E., Jacques, N. A., and Hunter, N.: Determination of bacterial load by real-time PCR using a broadrange (universal) probe and primers set, Microbiology, 148, 257266, https://doi.org/10.1099/00221287-148-1-257 2002. 
Niederdorfer, R., Peter, H., and Battin, T. J.: Attached biofilms and suspended aggregates are distinct microbial lifestyles emanating from differing hydraulics, Nat. Microbiol., 1, 1-7, https://doi.org/10.1038/nmicrobiol.2016.178, 2016.

Nilsen, V., Wyller, J., and Heistad, A.: Efficient incorporation of microbial metabolic lag in subsurface transport modeling, Water Resour. Res., 48, 1-9, https://doi.org/10.1029/2011WR011588, 2012.

Ostojić, A., Rosado, J., Miliša, M., Morais, M., and Tockner, K.: Release of Nutrients and Organic Matter from River Floodplain Habitats: Simulating Seasonal Inundation Dynamics, Wetlands, 33, 847-859, https://doi.org/10.1007/s13157-013-0442-9, 2013.

Rinklebe, J. and Langer, U.: Microbial diversity in three floodplain soils at the Elbe River (Germany), Soil Biol. Biochem., 38, 2144 2151, https://doi.org/10.1016/j.soilbio.2006.01.018, 2006.

Sapronov, D. V. and Kuzyakov, Y. V.: Separation of root and microbial respiration: Comparison of three methods, Eurasian Soil Sci., 40, 775-784, https://doi.org/10.1134/s1064229307070101, 2007.

Schimel, J., Balser, T. C., and Wallenstein, M.: Microbial stressresponse physiology and its implications for ecosystem function, Ecology, 88, 1386-1394, https://doi.org/10.1890/06-0219, 2007.

Slater, L. D., Ntarlagiannis, D., Day-Lewis, F. D., Mwakanyamale, K., Versteeg, R. J., Ward, A., Strickland, C., Johnson, C. D., and Lane, J. W.: Use of electrical imaging and distributed temperature sensing methods to characterize surface water-groundwater exchange regulating uranium transport at the Hanford 300 Area, Washington, Water Resour. Res., 46, 1-13, https://doi.org/10.1029/2010WR009110, 2010.

Stegen, J. C., Fredrickson, J. K., Wilkins, M. J., Konopka, A. E., Nelson, W. C., Arntzen, E. V., Chrisler, W. B., Chu, R. K., Danczak, R. E., Fansler, S. J., Kennedy, D. W., Resch, C. T., and Tfaily, M.: Groundwater-surface water mixing shifts ecological assembly processes and stimulates organic carbon turnover, Nat. Commun., 7, 1-12, https://doi.org/10.1038/Ncomms11237, 2016.

Tockner, K., Malard, F., and Ward, J. V.: An extension of the flood pulse concept, Hydrol. Proc., 14, 2861-2883, https://doi.org/10.1002/10991085(200011/12)14:16/17<2861::AID-HYP124>3.0.CO;2-F, 2000.
Tonina, D. and Buffington, J. M.: Hyporheic Exchange in Mountain Rivers I: Mechanics and Environmental Effects, Geography Compass, 3, 1063-1086, https://doi.org/10.1111/j.17498198.2009.00226.x, 2009.

USACE: National Inventory of Dams US Army Corps of Engineers, http://nid.usace.army.mil/cm_apex/f?p=838:4:0::NO (last access: 27 June 2017), 2016.

Trimmer, M., Grey, J., Heppell, C. M., Hildrew, A. G., Lansdown, K., Stahl, H., and Yvon-Durocher, G.: River bed carbon and nitrogen cycling: state of play and some new directions, Sci. Total Environ., 434, 143-158, https://doi.org/10.1016/j.scitotenv.2011.10.074, 2012.

Warren, C. R.: Response of osmolytes in soil to drying and rewetting, Soil Biol. Biochem., 70, 22-32, https://doi.org/10.1016/j.soilbio.2013.12.008, 2014.

Weatherburn, M.: Phenol-hypochlorite reaction for determination of ammonia, Anal. Chem., 39, 971-974, https://doi.org/10.1021/ac60252a045, 1967.

Wood, B. D., Ginn, T. R., and Dawson, C. N.: Effects of microbial metabolic lag in contaminant transport and biodegradation modeling, Water Resour. Res., 31, 553-563, https://doi.org/10.1029/94WR02533, 1995.

Wörman, A., Packman, A. I., Johansson, H., and Jonsson, K.: Effect of flow-induced exchange in hyporheic zones on longitudinal transport of solutes in streams and rivers, Water Resour. Res., 38 , 1-15, https://doi.org/10.1029/2001WR000769, 2002.

Zarfl, C., Lumsdon, A. E., Berlekamp, J., Tydecks, L., and Tockner, K.: A global boom in hydropower dam construction, Aquat. Sci., 77, 161-170, https://doi.org/10.1007/s00027-014-0377-0, 2015.

Zarnetske, J. P., Haggerty, R., Wondzell, S. M., and Baker, M. A.: Dynamics of nitrate production and removal as a function of residence time in the hyporheic zone, J. Geophys. Res.-Biogeo., 116, 1-12, https://doi.org/10.1029/2010JG001356, 2011.

Zeglin, L. H., Dahm, C. N., Barrett, J. E., Gooseff, M. N., Fitpatrick, S. K., and Takacs-Vesbach, C. D.: Bacterial Community Structure Along Moisture Gradients in the Parafluvial Sediments of Two Ephemeral Desert Streams, Microb. Ecol., 61, 543-556, https://doi.org/10.1007/s00248-010-9782-7, 2011. 